\title{
ROMÁNIA MEZŐGAZDASÁGÁNAK VIZSGÁLATA, KÜLÖNÖS TEKINTETTEL AZ EU-CSATLAKOZÁS UTÁNI IDŐSZAKRA
}

\author{
Nagy Szeréna
}

\section{Összefoglalás}

A mezögazdaság létfontosságú tevékenység, amelynek meghatározó sz̨erepe van a lakosság élelmezésbiztonságában, hatást gyakorol a regionális és helyi ökoszisztémákera és minden ország gazdasági fejlödésének egyik esžoözu. Tény, hogy a mezógazdaság nemzetgazdasági jelentösége a legtöbb országban csökkent az elmúlt idöszakban, azonban ma sem kerülhetö meg az agrárium nemzetgazdasági szerepe Romániában és más országok esetében sem.

A jelenlegi tanulmány célja, hogy megvizsgálja, bemutassa a romániai mezógazdaság helyzetét, átalakulását az. elmúlt években, különös tekintettel az uniós csatlakozás utáni évekre. Cél volt továbbá egy olyan végkövetkeztetés levonása, amely tartalmazza a legfontosabb muiltbeli tendenciákat, a román mezógazdaság sajátosságait és egy jövöbeli perspektivát is megfogalmaz az aktuális, globális mezögazdasági kihivások, problémák fényében. A cél elérése érdekében olyan makrogazdasági mutatók has nnálatára került sor, mint a GDP, a GO, a földhasználat, a mezógazdasági ágazatok vizsgálata (növénytermesztés, állattenyésztés) és a mezógazdasági output.

Kulcsszavak: mezógazđdasági szeektor, teljesitmény, GDP, foglalkoztatás, földhasználat

JEL: Q10

\section{ANALYZE OF THE ROMANIAN'S AGRICULTURE ESPECIALLY IN THE POST EU ACCESSION PERIOD}

\begin{abstract}
Agriculture is a vital activity that plays a key role in the food security of the population and has a great impact on the regional and local ecosystems, becoming a strategic tool for the economic development of any country.

The role and the importance of the agriculture sector in the national economy has declined in most countries, but on the other hand the role of agriculture in Romania and other countries cannot be circumvented nowadays.

The purpose of the study is to analyze, identify the place and the role of agriculture in Romania's actual economy from the perspective of GDP, the employment of this sector activity, because Romanian agriculture remains an important sector in terms of view of agricultural area used, the contribution to GDP and, in particular, the percentage of the rural population employed.
\end{abstract}

Keywords: Agriculture sector, productivity, GDP, employment, land use JEL: Q10 


\section{Bevezetés}

A gazdaság globális helyzetének vizsgálata esetében elengedhetetlen jelentőségű, hogy az országok, kisebb területi egységek, régiók gazdasági helyzetét is elemezzük. Az Európai Unió, mint gazdasági és politikai egység, jelenleg 27 tagállam szövetsége, a világgazdaság megkerülhetetlen jelentőségû szereplője. Az Európai Unió működésének vizsgálata szempontjából kiemelt jelentőséggel bír az egyes országcsoportok múködésének, gazdasági helyzetének elemzése (Vasa, 2011; Fenyves et al. 2019; Fenyves et al. 2020). A gazdasági növekedés és annak üteme a nemzetgazdasági ágazatok teljesítményétől és hatékonyságától függ (Ionescu et al., 2019). Az agrár-élelmiszerágazat helye, szerepe, teljesítménye a nemzetgazdaságban nagymértékben függ a felhasznált inputtényezók mennyiségétől, minőségétől és az outputtól is (Kovács, 2010).

Az EU-28 esetében vannak olyan országok (Csehország, Bulgária, Románia, Szlovénia, Lengyelország), ahol a mezőgazdaság teljesítménye alacsony az EU-28 átlaghoz képest. Erre lehet egy példa Románia, amely adottságai és erőforrásai tekintetében egyaránt megfelelő az állattenyésztésre és növénytermesztésre is, ugyanakkor az agrárium teljesítménye alacsony az EU-28 szinthez hasonlítva. Ha egy hatékonyság-fenntarthatóság koordinátarendszerben helyeznénk az eltérő fejlettségú országok mezőgazdaságát, akkor két végponpontot tudnánk beazonosítani, amely közül az egyik a nagyon fejletlen, teljesítményben is gyenge, de környezetkímélő mezőgazdasággal bíró országok csoportja lenne, míg a másik végpontján a fejlettebb országok szerepelnének (Steriu et al., 2013). Romániában a mezőgazdaság mindig meghatározó nemzetgazdasági szereppel bírt, kiemelkedő a jelentősége a foglalkoztatásban is. A rendszerváltás, a privatizáció, a változó jogi keretek és az Európai Unióhoz való csatlakozás hatására a romániai mezőgazdaság jelentős változásokon ment keresztül (Bors, 2007; Dajnoki et al. 2020). Az Európai Unióhoz való csatlakozást követően Románia nem tudta felvenni a versenyt a régi tagországokkal, amely a következő tényezőknek köszönhető: az alacsony szervezettség, felszereltség, korszerűtlen technológia, a mezőgazdaságban dolgozók megfelelő szaktudásának hiánya, elaprózódott birtokstruktúra (Samochiş et al. 2012). Másfelől a mezőgazdaság globális problémáival a romániai agráriumnak is szembe kell néznie. Ilyen problémát jelent a népesség globális növekedése, a változó fogyasztási szerkezet, a szűkösen rendelkezésre álló erőforrások és a klímaváltozás kérdésköre. Mindezzel párhuzamosan a termőföldek mintegy negyede már napjainkra is veszít termőértékéből, miközben egyre szélesebb körben válnak ismertté a biodiverzitás csökkenésének és az éghajlat változásának káros hatásai. Miközben az élelmiszerek, a takarmány és a magas rosttartalmú növények iránti igény folyamatosan emelkedik, addig a veszélyeztetett állapotban lévő termőföldekre és az elérhető édesvíz-háztartásra egyre nagyobb nyomás nehezedik. Az élelmiszerek és takarmányok termelésére használt földterületek nagysága és egymáshoz viszonyított aránya nagyban függ a globális étkezési szokások, valamint az elérhetô termésátlagok alakulásától (FAO, 2017; Fróna et al. 2019).

\section{Anyag és módszer - Tudományos koncepció és módszerek}

A szekunder információgyüjtés során statisztikai kiadványok, valamint nemzetközi és hazai tudományos közlemények, szakkönyvek, tanulmányok használata által vizsgálom Románia mezőgazdaságát az Európai Unióhoz való csatlakozást követően. A számszerű adatok gyűjtése során az EUROSTAT, WORLD BANK, FAO, INSSE adatbázisait használom. Továbbá kutatóintézetek 
és a Romániai Statisztikai Hivatal felméréseit, elemzéseit tanulmányozom át és dolgozom fel. Kutatásom részét képezi az adatbázisok, fellelhető releváns adatok feldolgozása Microsoft Excel program segítségével.

\section{Szakirodalmi áttekintés}

A fejlett országok esetében a mezőgazdaság hozzájárulása a GDP termeléshez alacsony, illetve a mezőgazdaságban dolgozók aránya is folyamatosan csökken. A folyamat egyik alapvető oka az élelmiszertermékek iránti kereslet jövedelemrugalmatlansága (Kemény et al. 2012; Herman et al. 2018; Popp et al. 2018). Mindezek ellenére a mezőgazdaság még mindig számottevő nemzetgazdasági ágazat. Másfelől globális szinten ma is közvetlenül vagy közvetve a nemzetgazdaságban legalább minden hetedik munkahely a mezőgazdasághoz kötődik. Vagyis egy olyan jelentős gazdasági ágazatról beszélünk, amelynek meghatározó szerepe van és ezen ágazat hatékonysága, versenyképessége, fejlesztése nagymértékben meghatározza az egész nemzetgazdaság helyzetét (Kovács, 2010; Farkasné et al. 2014).

Románia magas mezőgazdasági potenciállal rendelkezik, ennek ellenére van néhány olyan tényező, amely gátolja a mezőgazdaság hatékonyságának növekedését. A gazdák sajnos nem rendelkeznek megfelelő szintû technológiai ellátottsággal, megfelelő szakértelemmel, tudással, öntözési berendezésekkel, illetve a másik probléma, hogy a mezőgazdasági ágazatba alacsony a befektetési hajlandóság (Radu, 2018). Ugyanakkor a mezőgazdaság az egyik alapvető ágazata a romániai nemzetgazdaságnak, megközelítőleg 3,5 millió kisgazdaság múködik, amelyek a gazdaságok 90\%-át teszik ki (Péter - Illyés 2019). A 2018-as adatok szerint Romániában a mezőgazdaság, erdőgazdálkodás, halászat a GDP termeléshez 6\%-kal járult hozzá, amíg az Európai Unióban 1,7\%-kal (Radu, 2018). A mezőgazdasági ágazat egészen az 1989-es évekig egy dinamikusan fejlődő ágazatnak számított Romániában, illetve nagy mértékben hozzájárult a GDP termeléséhez is. 1989 után, elsősorban a degradált, korszerútlen technológia használata következtében, illetve a rendszerváltás okozta nehézségek, új társadalmi, jogi és politikai berendezkedés hatása miatt a mezőgazdaság hozzájárulásának aránya az ország gazdasági teljesítményéhez csökkent. A rendszerváltást követő években a romániai mezőgazdaság teljesítménye romlott, ugyanis eltûntek azok az alapvető mezőgazdasági allappillérek (mezőgazdasági szövetkezetek, állami mezőgazdasági vállalkozások), amelyek megalapozták a mezőgazdaság tartós ütemű fejlődését illetve produktivitását. A romániai agrártörténelem következő meghatározó mérföldköve az Európai Unióhoz történő csatlakozás volt, amely ismét egy teljesen új, idegen és szokatlan gazdasági, jogi, piaci átalakulást jelentett az agrárium számára is (Dávid et al., 2008; Anca, 2011). A gazdák mentalitásában még mindig meghatározó szerepe volt az 1989-es tapasztalatoknak, koncepcióknak, ebben a tekintetben nagyon nehezen tudták befogadni a szabadpiac koncepcióját és annak múködését is. Az idősebb korosztálynál jelenleg is beazonosítható a mezőgzdasági vállalkozások jogi formájának választása estében egyfajta félelem, idegenkedés a szövetkezetek hallattán. Az Európai Unióhoz való csatlakozás a romániai agráriumot felkészületlenül érte. Romániában az 1990-es évek után folyamatos a gazdasági átalakulás, a megváltozott piaci viszonyok a mezőgazdaság és az élelmiszeripari termelés nagymértékű visszaesését eredményezte. A rendszerváltást követően a földprivatizációs folyamatok eredményeként létrejövő árutermelés helyett az önellátást biztosító kisgazdaságok elterjedése jellemző, amelyek elsősorban a család megélhetését segítő tevékenységet szolgálják (Elek et al. 2009). 
A 2007 utáni években a romániai mezőgazdasági szereplőknek az elsődleges problémát a verseny jelentette, ugyanis jelentős nehézséget jelentett a régi tagállamok mezőgazdasági termelőivel felvenni a versenyt, amelynek egyik magyarázata a tőkehiány. Az állattenyésztési ágazatok jövedelmezősége visszaesett, ugyanakkor a növénytermesztés és az állattenyésztés esetében is kijelenthetô, hogy az Európai Unióhoz való csatlakozást követően a hazai termelésű, állati és növényi eredetű élelmiszerek aránya a lakossági fogyasztásban jelentôsen csökkent, kivitelük viszont nem nôtt (Cecilia et al. 2013). A csatlakozás után kibontakozott válság tovább gyengítette Románia gazdasági helyzetét. Ugyanakkor a válságot követően, 2010 után Románia mezőgazdasági outputja folyamatosan növekedett, amelynek egyik alapvető oka az volt, hogy javult a mezőgazdasági termelékenység. A csatlakozást követően, az új támogatási rendszer keretén belül, a területalapú támogatások által a gazdák az egy hektárnál nagyobb megművelt parcellákra pénzbeli támogatásban részesültek. Ennek ösztönző szerepe volt, ugyanis ez által olyan földterületek is bekerültek a termelés körforgásában, amelyek a csatlakozás előtti időszakban nem voltak megművelve és használva. Tulajdonképpen a csatlakozás utáni nyolc évben a nagyobb gazdaságok jelentős növekedése ment végbe, a kisebb gazdaságok gazdasági tevékenysége megszűnt, de a közepes gazdaságok esetében is szintén egy növekedés ment végbe (Unguru, 2017; European Commission, 2013).

Anghel, Anghelache és Panait 2017-ben készítettek egy tanulmányt, amelyben megvizsgálták Románia illetve egyes Európai Uniós tagállamok mezőgazdasági teljesítményét. Az előbb említett tanulmány elemzési szempontjai voltak a növénytermesztés, állattenyésztés teljesítményének vizsgálata, a mezőgazdaság hozzáadott értékének elemzése, illetve egyes termelési tényezők használatának elemzése. A tanulmány szerint Románia mezőgazdasági inputtényezőinek tekintetében 7 . helyen szerepel az Európai Unió szintjén, tehát magas mezőgazdasági potenciállal rendelkezik, viszont a 2007-es csatlakozást követően beazonosítható egy csökkenő tendencia az állattenyésztés és a növénytermesztés arányát illetően is (Anghel et al., 2017).

\section{A föld, mint inputtényezö}

A mezőgazdaság termelési tényezői közül alapvető jelentőséggel bír a föld. Románia területe 238 391 négyzetkilométer, amelynek 58,77\%-a mezőgazdasági terület (INSSE, 2018). Románia mezőgazdasági területe 14,7 millió ha (INSSE, 2018; World Bank, 2018), ez az érték hozzávetőleg 8\%-a az EU-27 mezőgazdasági területének, ugyanakkor a mezőgazdasági terület aránya az 1968-2016 közötti időszakban jelentősen csökkent. Az Eurostat 2018-as adatai alapján a romániai gazdaságok többségének, 92\%-ának mezőgazdasági területe 5 hektárnál kisebb, ez a legmagasabb arány az EUban, illetve a romániai gazdaságok 0,5\%-a rendelkezik 50 hektárnál nagyobb mezőgazdasági földterülettel (Eurostat, 2018; INSSE, 2018). Az 1. ábra szemlélteti, hogy az összes földterület hány százaléka mezőgazdasági terület Romániában és az EU-28 egyes országaiban a 2007 és 2016 közötti időszakban. 


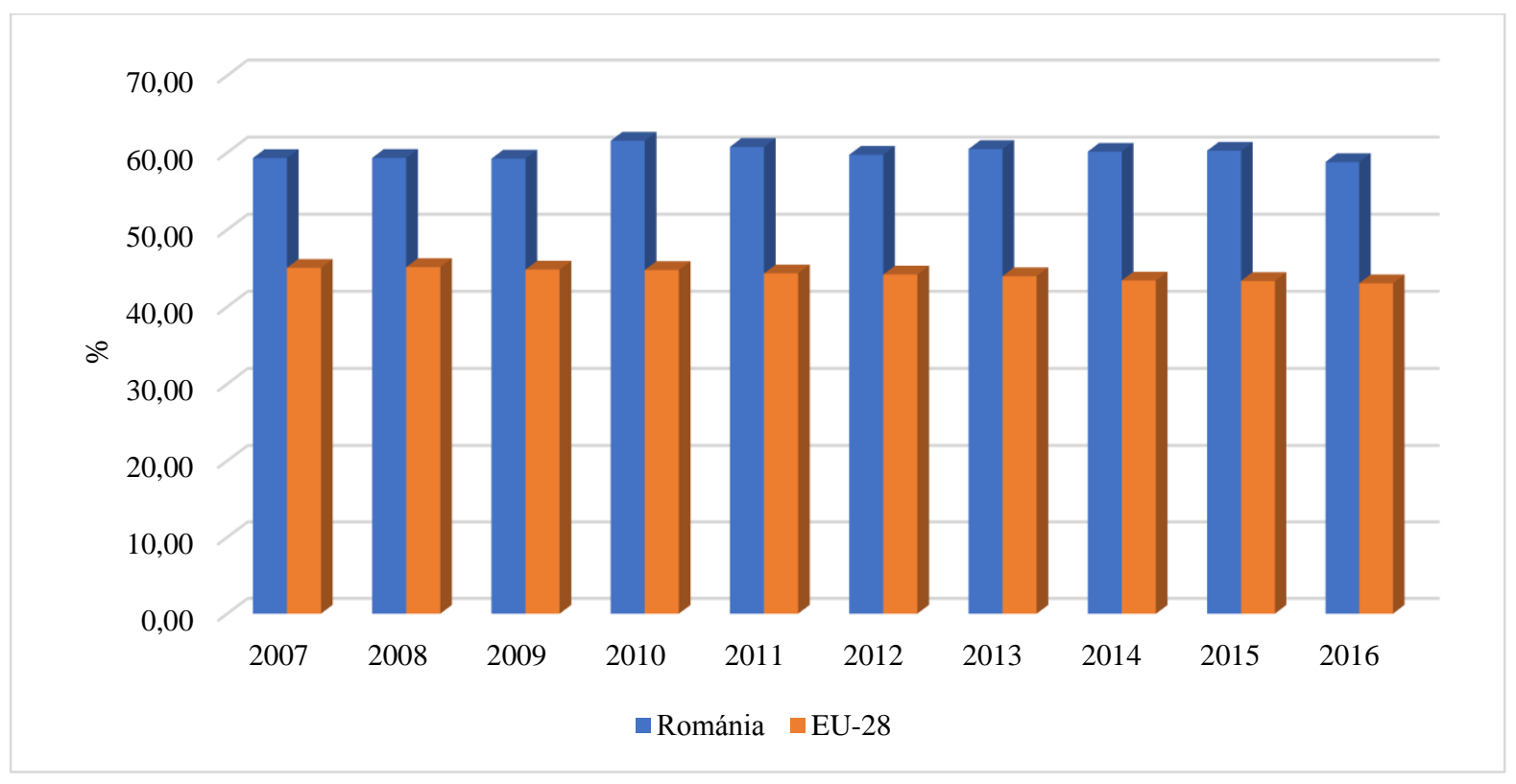

\section{1. ábra. A mezőgazdasági terület aránya az összes földterületből Romániában és az EU- 28 tagállamaiban (2007-2016, \%) \\ Forrás: Nagy (World Bank, 2016) adatok alapján}

A fajlagos terület-ellátottságot vizsgálva megállapítható, hogy az egy lakosra eső mezőgazdasági terület nagysága Romániában 0,43 ha, míg az EU 28 hasonló értéke 0,23 ha (World Bank, 2016). Ezzel a földállománnyal Románia Lengyelország után a második helyet foglalta el a kelet-középeurópai országok közül, az EU 28-ban pedig a 7. helyet. Romániát a 2016-os adatok alapján a mezőgazdasági földterület nagysága szempontjából megelőzte Franciaország, Spanyolország, Lengyelország, Németország és Nagy-Britannia (World Bank, 2016).

A 2013-2016-os időszakban csökkent a mezőgazdasági üzemek száma, de növekedett a mezőgazdaságban felhasznált, megművelt földterületek aránya. A továbbiakban is fontos és szükséges a földterületek tagosítása, annak érdekében is, hogy a korszerű, hatékony arotechnológia használható legyen (Constantin, 2018). Románia természeti adottságai tekintetében kijelenthető, hogy az ország területének több mint 50\%-a használható mezőgazdasági területként, ugyanakkor a rendszerváltás utáni romániai földtörvény a mezőgazdasági földterületek fragmentációját okozta. A romániai gazdaságok 75\%-a 2 ha alatt van, illetve a 100 ha feletti földterülettel rendelkező farmok aránya $0,5 \%$, amelyek a rendelkezésre álló mezőgazdasági földterületek 49\%-ának a megművelését végzik (Radu, 2018).

\section{Munkaerő a mezőgazdaságban}

Az emberi erőforrásnak, mint a termelés egyik inputtényezőjének mindig meghatározó szerepe volt a mezőgazdaságban, ugyanakkor ez egy olyan specifikus jelleggel bíró erőforrás, amelynek véges a munkaerőpiacon levő kínálata, megújulási és tanulási képességekkel rendelkezik, amelyet nagymértékben befolyásol a munkavállalók egyéni motivációja (Magda et al. 1998). Ha a mezőgazdaság humán munkaerôkeresletét vesszük figyelembe, akkor kijelenthető, hogy ez az egyik olyan ágazat, 
amely esetében magas a kereslet a humán tőke iránt, ugyanis az állattenyésztésben, de a növénytermesztésben és azon belül a zöldségtermesztésben is az emberi erőforrás jelenti az egyik alapvetô, a termelés szempontjából fontos inputtényezőt.

Napjainkban átértékelődik az emberi erőforrás jelentősége, hiszen a mezőgazdasági vállalkozások számára az egyik alapvető kihívást a megfelelő szaktudással rendelkező munkaerő megtalálása és megtartása jelenti. A vállalati gazdálkodás egyik legfontosabb erőforrásának a megfelelően motivált, hasznos tudással és képeségekkel rendelkező dolgozók nevezhetők (Magda et al. 1998; Kőmíves et al. 2019). Románia lakossága 19473936 volt 2018-ban, ebből 51,1\% nő, illetve 48,9\% férfi. A lakosság 53,6\%-a városokban él, míg 46,4\%-a vidéken (Bujdosó et al. 2015). A vidéki lakosság elsődleges megélhetési forrása a mezőgazdaság (INSSE, 2018). A fejlett mezőgazdasággal rendelkező országok esetében beazonosítható egy csökkenő tendencia az ágazatban dolgozók arányának tekintetében. A mezőgazdasági munkaerő vizsgálatának esetében kijelenthető, hogy Románia esetében magas a mezőgazdaságban dolgozók aránya, ugyanis a 2018-as World Bank adatok alapján Romániában a mezőgazdaságban dolgozók aránya 23\% volt, míg az Európai Unióban csak $3 \%$, ugyanakkor az esetek jelentős hányadában tulajdonképpen önellátásról beszélhetünk (Fróna et al. 2019). Annak ellenére, hogy az országban magas a mezőgazdaságban dolgozók aránya, a lakosság nagy része állandó, illetve szezonális mezőgazdasági munkaerôként van jelen más európai uniós országokban (Németország, Franciaország, Olaszország, Dánia, Spanyolország) (INSSE, 2018). Az Európai Unió tagállamai közül Romániában a legmagasabb a mezőgazdaságban dolgozók aránya, ugyanis 2018-ban ez az érték itt - a korábban már említettek szerint - 23\%, míg Franciaországban 4,31\%, Németországban 3\%, Spanyolországban 4\%, Lengyelországban pedig 10\% volt. A 2. ábra szemlélteti, hogy a 2007 és 2018 közötti időszakban hogyan alakult a mezőgazdaságban dolgozók aránya Romániában.

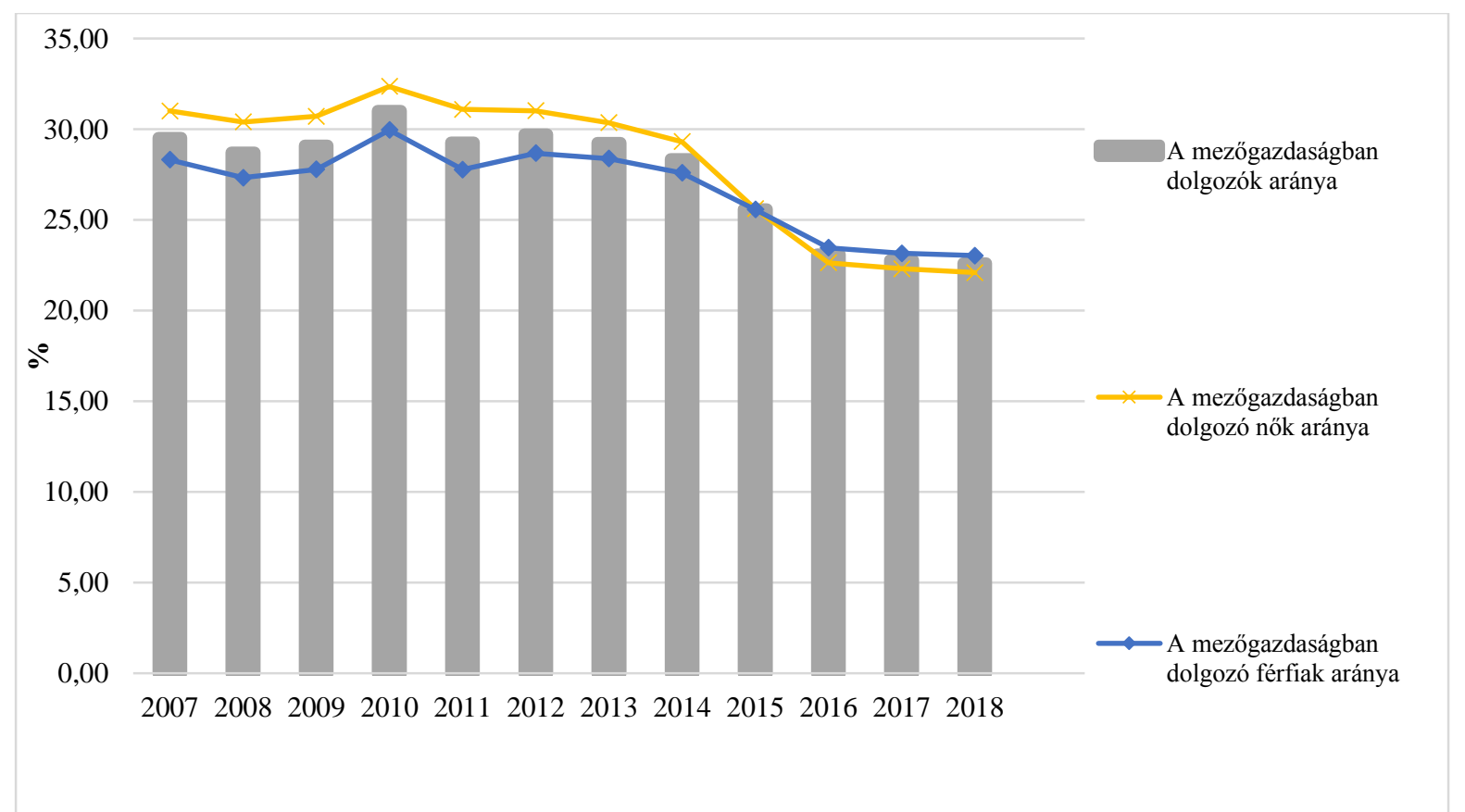

2. ábra. A mezőgazdaságban dolgozók aránya Romániában a munkaképes korú lakosság arányában, illetve nemenkénti bontásban (2007-2018, \%)

Forrás: Nagy (World Bank, 2018) adatok alapján 
A rendszerváltást követően egészen a 2000-es évekig a mezőgazdaságban dolgozók aránya növekedett, majd 2000 után volt egy csökkenés, illetve a gazdasági válságot követő években, a válság hatására a mezőgazdaságban dolgozók aránya emelkedni kezdett. Ennek az egyik oka, hogy a gazdasági válság hatására nőtt a munkanélküliség, ugyanis a szekunder, illetve tercier szektor esetében is csökkent a foglalkoztatottság aránya. Ennek tekintetében 2008-ban a munkaképes korú lakosság 32\%-a dolgozott a szekunder szektorban, 2009-ben ez az arány 30\% volt, illetve 2010-ben 28\%-ra csökkent. Ezzel párhuzamosan 2008-ban a munkaképes korú lakosság 28\%-a, 2009-ben 29\%-a, 2010-ben 31\%-a dolgozott a mezőgazdaságban (World Bank, 2018). Ahogyan a fenti ábra is szemlélteti a 2013-2016-os idôszakban a mezőgazdaságban dolgozók aránya folyamatosan csökkent, 2013-ban 2380 fö, 2014-ben 2304 fö, 2015-ben 2003 fö, 2016-ban 1727 fö dolgozott hivatalos munkaszerződéssel a mezőgazdaságban (INSSE, 2018). A csökkenés ellenére az Európai Unióval összevetve Románia értékei ezen a téren továbbra is magasak. Ebben az idôszakban az elôbb említett csökkenésnek több oka is lehet, az első ilyen tényező, hogy Románia népessége is folyamatosan csökkent a 1990-es évekhez viszonyítva (23 millió főről immár 20 millió fő alá), de ha a 2007es évet vesszük viszonyítási alapként, akkor is érzékelhető csökkenés, ugyanis 2007-ben Románia lakossága 20882 982, 2018-ban 19473936 (World Bank, 2018). Ugyanakkor a Román Statisztikai Hivatal 2018-as adatai alapján kijelenthető, hogy a 2013-2016-os időszakban a szekunder szektorban dolgozók aránya növekedett, vagyis 2013-ban 1778 fö, 2014-ben 1782 fö, 2015-ben 1872 fó, 2016-ban 1957 fő dolgozott hivatalos munkaszerződéssel a szekunder szektorban (INSSE, 2019). Másfelől 2007-ben belépett Románia az EU-ba, vagyis ezáltal a Romániában élő polgárok számára lehetőség adódott más uniós tagállamokban is munkát vállalni a szabad munkaerő-áramlásnak köszönhetően. Romániában, és különösen a romániai mezőgazdaságban sokan éltek ezzel a lehetőséggel, ugyanis az agráriumban elérhető munkabér, jövedelem nem volt és jelenleg sem versenyképes más uniós tagállamok munkabérével, jövedelmével. Egy másik perspektíva és egyben magyarázat a mezőgazdaságban dolgozók arányának csökkenésére, hogy a szakmunkások más területeken vállaltak munkát, így például a tercier szektorban. Utóbbi esetében a 2007-2018-as időszakban jelentősen megnőtt a munkavállalók aránya, ugyanis míg 2007-ben a lakosság 39\%-a vállalt munkát a tercier szektorban, addig 2018-ban a lakosság 47\%-a. Ezzel ellentétben a mezőgazdaságban ez az arány 2007-ben 30\%, míg 2018-ban 23\% volt (INSSE, 2018; World Bank, 2018). Megfelelő szakértelem és tudás hiánya beazonosítható a gazdák esetében is, vagyis a romániai gazdák többsége csak gyakorlati tudással rendelkezik és csupán 7\%-uk rendelkezik alap vagy felsőfokú mezőgazdasági végzettséggel (Radu, 2018).

\section{Bruttó hazai termék}

A mezőgazdaság GDP termeléshez való hozzájárulását vizsgálva kijelenthető, hogy a román gazdaság egyik legfontosabb, legmeghatározóbb ágazata (Mănescu et al. 2016). Románia gazdasági fejlődésében a mezőgazdaság alapvető fontosságú, hiszen az ország teljes területének 58,7\%-a mezőgazdasági terület, emellett igen magas a szektor lakossági foglalkoztatásban betöltött szerepe is. 


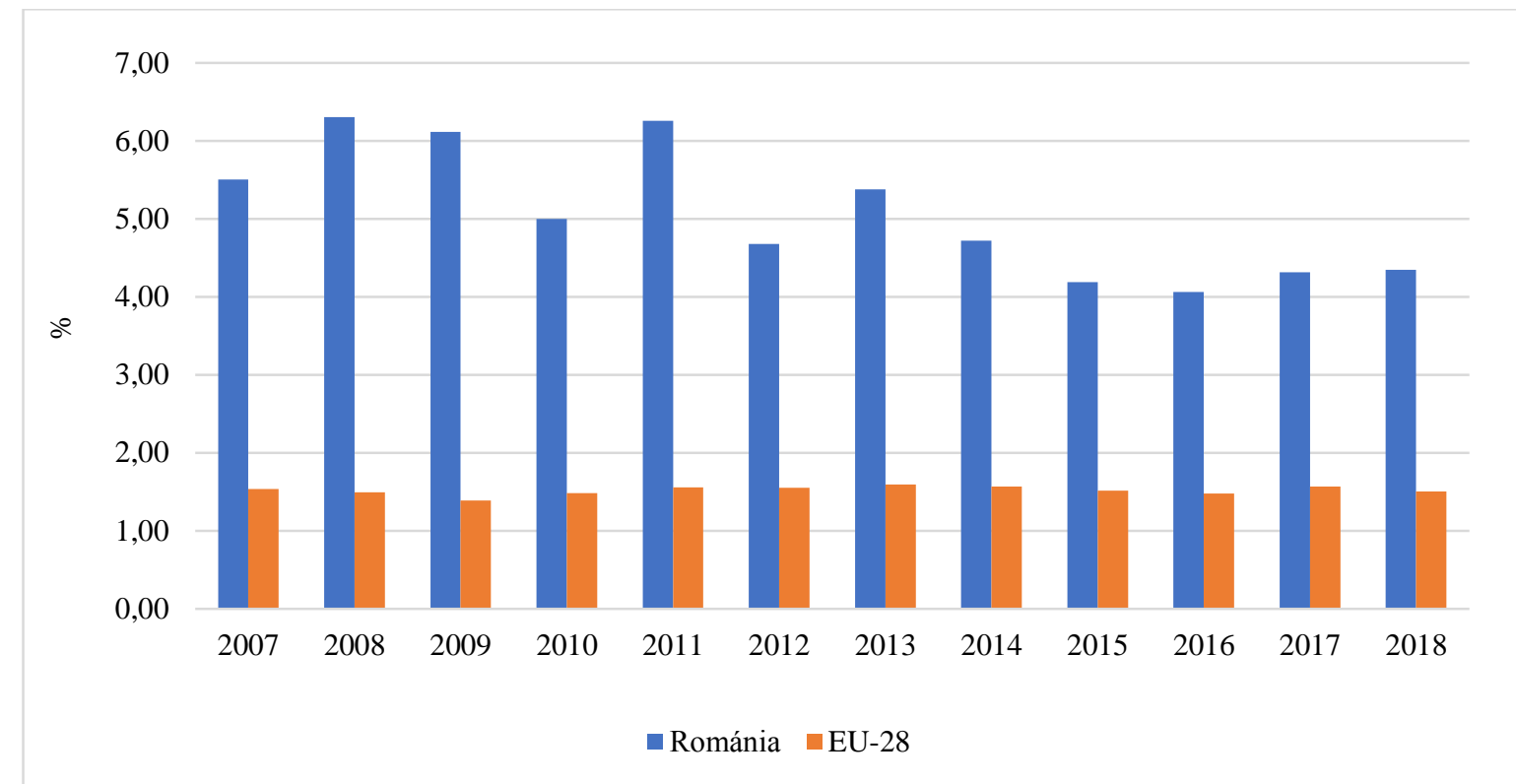

3. ábra. A mezőgazdaság, erdőgazdálkodás és halászat hozzájárulásának aránya a GDP termeléshez Romániában és az EU-28 tagállamaiban (2007-2018, \%)

Forrás: Nagy (World Bank, 2018; INSSE, 2018) adatok alapján

Romániában a mezőgazdaság, erdőgazdálkodás és halászat GDP-hez való hozzájárulásának aránya az elmúlt 11 évben csökkent. Látható, hogy 2007-ben 5,5\% volt ez az érték, míg 2018-ban már csak 4,34\%. Ugyanakkor már a 2007-ben mért érték is jelentős visszaesést jelent az 1990-es évek 21\%-os részesedéséhez képest. Látható, hogy a mezőgazdaság hozzájárulásának aránya a GDP termeléséhez konstansan csökkent, ennek ellenére Romána egyike azon európai uniós országoknak, ahol a mezőgazdaság a GDP-termeléshez magas arányban járul hozzá. Az előbb említett csökkenés részben a román gazdaság strukturális átalakulásának köszönhető, amely átmenet során az ipariagrár gazdaságból szolgáltatásokra épülő gazdaság alakult ki. Romániában a mezőgazdaságban dolgozó személyek által generált bruttó hozzáadott érték mindössze 7\%, Franciaországban, illetve Spanyolországban 9\%. Az Európai Unió gazdaságainak egyharmada Romániában van, ennek ellenére az ország mezőgazdasági kibocsátása az európai szintű teljes kibocsátásnak csak 3,4\%-át teszi ki (European Commission, 2019). 


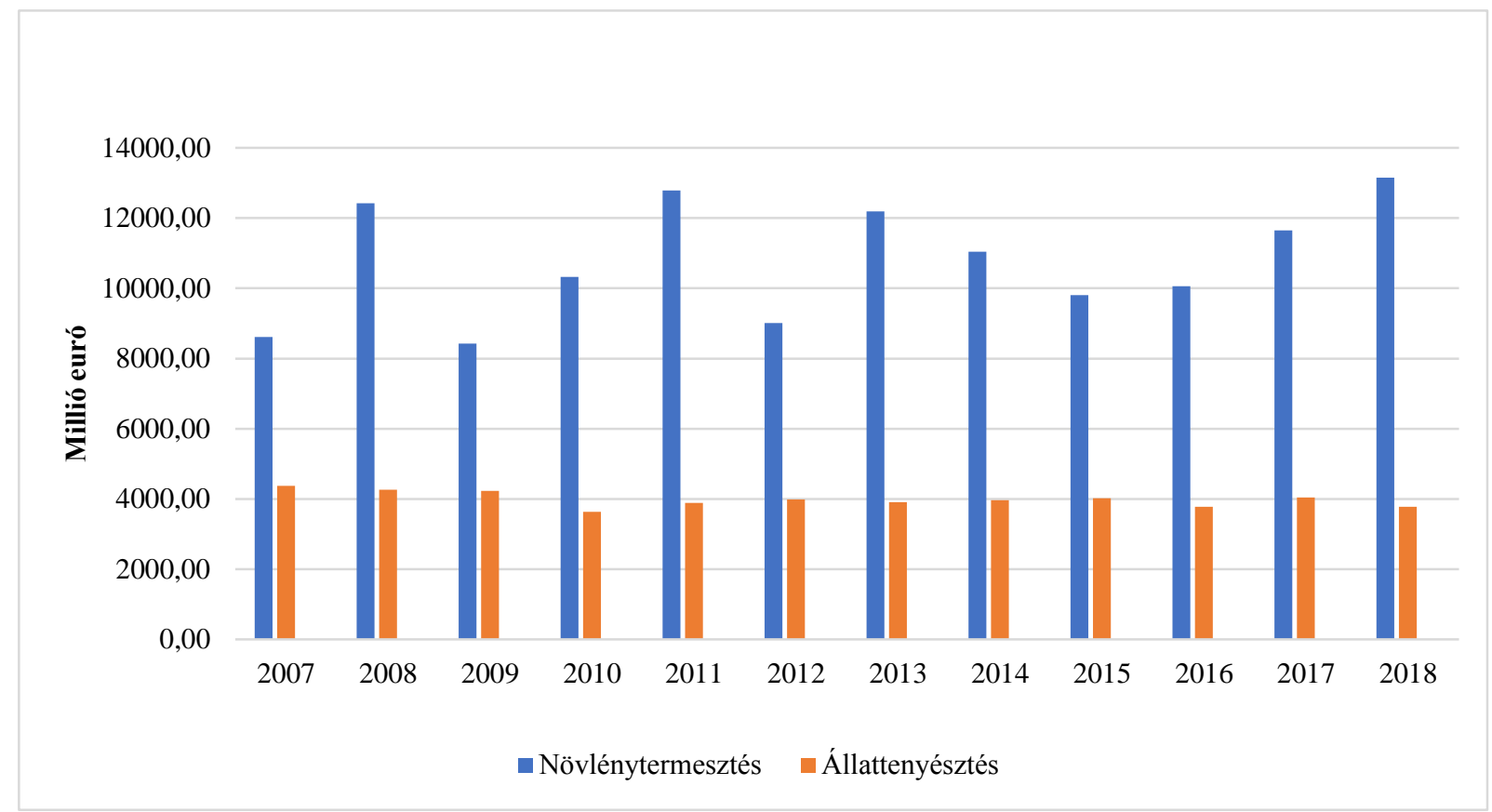

\section{4. ábra. Mezőgazdasági output Romániában (2007-2018, millió EUR)}

Forrás: Nagy (EUROSTAT, 2018) adatok alapján

A 2007-2018-as időszakban a romániai mezőgazdaság kibocsátási szerkezetét vizsgálva kijelenthető, hogy a növénytermesztés aránya folyamatosan növekedett, ezzel párhuzamosan az állattenyésztésé csökkent. Az Európai Unióhoz való csatlakozást követően Romániában felgyorsult az állattenyésztési ágazat leépülése (Unguru, 2017). Ennek az egyik alapvető oka lehet, hogy a növénytermesztési ágazat jövedelmezősége a területalapú támogatások hatására megnövekedett. Másfelől a növénytermesztés kevésbé humántőkeigényes ágazat, ugyanis a romániai a mezőgazdaság egyik problémája a megfelelő szakértelemmel rendelkező munkaerő hiánya.

A 2018-as évben az Eurostat adatai alapján Romániában a növénytermesztési output aránya 75,4\%, az állattenyésztési output aránya pedig $23,2 \%$ volt. Az 5. ábra szemlélteti a 2018-as évben a mezőgazdasági ágazat output-struktúráját. Románia több mint 3,63 millió mezőgazdasági üzemmel rendelkezik, vagyis az EU gazdaságainak 33,5\%-a múködik az országban. Ez az arány jól tükrözi a kisgazdaságok domináns jellegét, amelyek egyik jellemzője a kisebb mezőgazdasági területek megművelésének aránya, illetve az alacsony termelési szint (Unguru, 2017). 


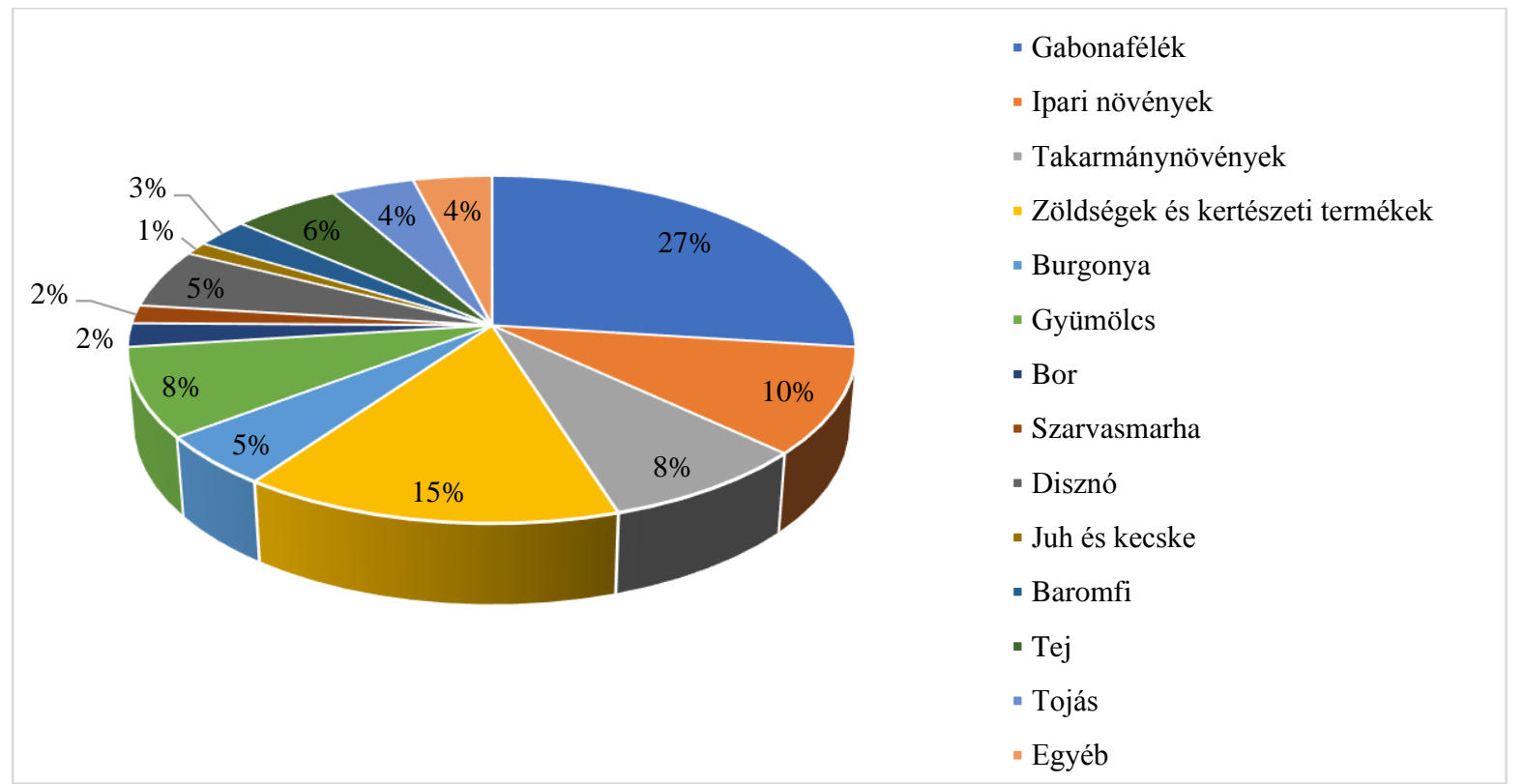

5. ábra. A növénytermesztés és állattenyésztési ágazat outputja Romániában 2018-ban a mezőgazdasági output arányában $(2018, \%)$ Forrás: Nagy (EUROSTAT, 2018) adatok alapján

Romániában az elmúlt években egyre magasabb a gabonatermesztés aránya, 2018-ban 27\% volt, amely az EU-28 gabonatermesztésének 10,4\%-át tette ki. Ugyanebben az évben az EU-28 gabonatermesztéséből Franciaország 21,2\%-kal, Németország 12,3\%-kal, míg Lengyelország 7,4\%-kal részesedett (European Commission, 2019). Romániában a növénytermesztés aránya magas, de még mindig problémát jelent a versenyképesség, vagyis Románia aktívabban részt kellene vegyen a globális és az európai uniós piacokon egyaránt (Constantin et al. 2019).

Az állattenyésztés területén annak ellenére, hogy az utóbbi 10 évben az ágazat aránya csökkent, a Romániában hagyományosnak tekinthető juhtenyésztésre továbbra is kiemelt figyelem hárult: a román állam különböző pályázati lehetőségeket teremett a gazdák számára, illetve jövedelemkiegészítő juttatások folyósításával is támogatta a juhtenyésztőket (Unguru, 2017; INSSE, 2018).

\section{Következtetések}

A fenti elemzés alapján látható, hogy Románia mezőgazdasága - úgy a növénytermesztés, mint az állattenyésztés tekintetében - rendelkezik olyan kiemelt jelentôségû, alapvető inputtényezőkkel, mint a föld, a humán erőforrás és a megfelelő természeti erőforrások, de ezen alapvető inputtényezők mindegyike esetében van néhány olyan jellemző, amely akadályozza a termelés eredményességének és a produktivitás hatékonyságának növelését. Az utóbbi években a pályázatoknak köszönhetően a gazdaságok technológiai ellátottsága javult, ami hozzájárult a produktivitás növekedéséhez, de továbbra is alapvető probléma a megfelelő szaktudás hiánya. A humán erőforrás tekintetében problémát jelent a mezőgazdaságban dolgozók szakképzettségének hiánya, illetve a mezőgazdasági munkavállalók fluktuációja. A föld, mint termelési tényező esetében az alapvető problémát a nadrágszijparcellás, felaprózott mezőgazdasági területek nagy száma jelenti, ami gátolja a hatékony termelést. A mezőgazdasági területek közel 70\%-át a nagytermelők birtokolják, a fennmaradt 30 százalékot pedig a kisgazdák. A területalapú támogatások is a nagygazdáknak kedveznek, ez pedig 
veszélyezteti a kisgazdaságok fennmaradását, működését. Az Európai Unió országain belül a földhasználat tekintetében jelentős különbségek figyelhetők meg, Romániában az 5 hektárnál kisebb gazdaságok száma jelentős. Annak ellenére, hogy a gazdák az ország földterületének $60 \%$-án gabonaféléket termesztenek, Románia importjának egyharmadát pékáruk, kenyér, fagyasztott tészták képezik, tehát a megtermelt gabonafélék nagy része külföldön kerül értékesítésre alapanyagként, amit feldolgozást követően késztermékként ismét az országban értékesítenek. Erősíteni kellene a feldolgozóipart annak érdekében, hogy a megtermelt alapanyagok az országban kerüljenek értékesítésre és feldolgozásra. Másfelől Romániában magas a mezőgazdaságban dolgozók aránya, de az nem jelenthetô ki, hogy hatékony is lenne a munkavégzés, tehát ebben a tekintetben az egyik cél a munkaerô hatékonyságának a növelése, illetve a korszerü üzemstruktúra kialakítása, ugyanis az utóbbi esetében jellemző, hogy magas az önellátó gazdaságok száma.

Összegzésképpen kijelenthető, hogy Románia mezőgazdaságának az alapvető problémái a megfelelő, korszerű technológia és a megfelelő szaktudással rendelkező munkaerô hiánya, a tőkehiány, továbbá az alacsony versenyképesség. Romániának egy olyan agrárstratégiát kell kidolgoznia, amely a fent említett problémák mellett hangsúlyt fektet a mezőgazdaság globális kihívásainak az orvoslására is, mint az éghajlatváltozás, fenntarthatóság, korlátozott mezőgazdasági erőforrások és hatékony termelés.

\section{Köszönetnyilvánítás}

A kutatás az EFOP3.6.3-VEKOP-16-2017-00007 - "Tehetségből fiatal kutató" - A kutatói életpályát támogató tevékenységek a felsőoktatásban. címú projekt keretében valósulhatott meg.

\section{Irodalomjegyzék}

[1.] Activity in the European Union. Romanian Statistical Review, Supplement 6, 63-74.

[2.] Anca, D. (2011): Contribuții ale agriculturii la fluctuațiile economice în România. Economie teoretică și aplicată , 18 (1), 154-165.

[3.] Anghel, M.G. - Anghelache, C. - Panait, M. (2017): Evoluția activității agricole în Uniunea Europeană. Romanian Statistical Review, Supplement 6.

[4.] Banca Națională a României (2018): Productivitatea sectorului agricol românesc - o abordare structurală. Letöltés dátuma: 2020. márciu.18. forrás: https://docplayer.ro/146586692-Productivitateasectorului-agricol-romanesc-o-abordare-structurala.html

[5.] Beke J. - Forgács A. (2010): A modern mezőgazdaság teljesítményének mérhetőségéről komparatív szektorelemzés. EU Working Papers, 16 (1), 89-101.

[6.] Bors R. (2004): A romániai mezőgazdasági átalakulás tapasztalatai, tekintettel az EU-csatlakozásra. Gazdálkodás, 48 (5), 30-40.

[7.] Bujdosó Z. - Pénzes J. - Madaras Sz. - Dávid L. (2015): Analysis Of The Spatial Trends Of Romanian Tourism Between 2000-2012. Geographia Technica, 10 (2), 9-19.

[8.] Cecilia, I. R. - Babucea, A. G. (2013): Economic aspects of the romanian agriculture evolution. Economy Series, issue (6), 95-100. 
[9.] Constantin, A. (2018): Analiza structurală a agriculturii românesti. Revista Română de Statistică Supliment (2), 3-10.

[10.] Constantin, A. - Tudor, S. - Radu, S. (2019): European Union policies on rural development of agriculture and industry. Romanian Statistical Review, Supplement (1), 176-187.

[11.] Dajnoki K. - Sipos N. - Héder-Rima M. - Kőmíves P. M. (2020): Mobilitás a határmenti régiókban - Románia. Pécsi Munkajogi Közlemények, 13 (Különszám), 101-128.

[12.] Date generale despre agricultura României (2015): Data explorer. Letöltés dátuma: 2020. március 24. forrás: https://www.madr.ro/docs/agricultura/agricultura-romaniei-2015.pdf

[13.] Dávid L. - Bujdosó Z. - Tóth G. (2008): Tourism planning in the Hajdú-Bihar - Bihor Euroregion, In: Süli-Zakar, I (szerk.) Neighbours and partners : on the two sides of the border Debrecen, Magyarország : Kossuth Egyetemi Kiadó pp. 323-332.

[14.] Elek S. - Fogarasi J. (szerk.) - Csata A. - Elek S (2009): A romániai agrárgazdaság EU csatlakozásának elsö tapasztalatai. Az európai uniós tagság kibivásai Székelyföldön. Kolozsvár: Scientia Kiadó

[15.] European Commission (2013): Evaluation of the structural effects of direct support. Letöltés dátuma: 2020. március 28. forrás: http://ec.europa.eu/agriculture/evaluation/market-andincomereports/2013/structuraleffects-direct-support/fulltext en.pdf

[16.] European Commission (2019): Statistical Factsheet. Letöltés dátuma: 2020. március 24. forrás: https:/ / ec.europa.eu/info/food-farming-fisheries/farming/facts-and-

figures/markets/production/production-country/statistical-factsheets en

[17.] EUROSTAT (2018): Europe in figures - Eurostat yearbook 2018: Agriculture, forestry and shery. Letöltés dátuma: 2020. március 24. forrás: https://ec.europa.eu/eurostat/web/productsstatistical-books/-/KS-HA-18-001

[18.] FAO (2017): The future of food and agriculture - Trends and challenges. Letöltés dátuma: 2020. március 24. forrás: http://www.fao.org/3/a-i6583e.pdf

[19.] Farkasné Fekete M. - Balyi Zs. - Szűcs I. (2014): Az agrárgazdaság hatékonyságának néhány sajátos aspektusa. Gazdálkodás, 58 (6). 564-594.

[20.] Fenyves V. - Pető K. - Szenderák J. - Harangi-Rákos M: (2020): The capital structure of agricultural enterprises in the Visegrad countries. Agricultural Economics - Zemedelska Ekonomika, 66 (4), 160-167. DOI: 10.17221/285/2019-agricecon

[21.] Fenyves V. - Pető K. - Harangi-Rákos M. - Szenderák J. (2019): A Visegrádi országok mezőgazdasági vállalkozásainak gazdasági és pénzügyi helyzete. Gazdálkodás, 63 (6 ), 459-473.

[22.] Fróna D. - Szenderák J. - Harangi-Rákos M. (2019): The challenge of feeding the world. Sustainability, 11 (20), 5816. DOI: $10.3390 /$ su11205816

[23.] Fróna D. - Kőmíves P. M. (2019): A mezőgazdasági munkaerő sajátosságai. Gazuálkodás, 63 (5). 361-380.

[24.] Herman S. - Körösparti P.- Kőmíves P. M. (2018): A magyar agrár-felsőoktatás aktuális helyzete. International Journal of Engineering and Management Sciences, 3 (4), 263-281. DOI: 10.21791/ijems.2018.4.23.

[25.] Institutul Național de Statistică (2017): Data explorer. Ancheta structurală în agricultură. Letöltés dátuma: 2020.25 .2 március forrás: http://www.insse.ro/cms/sites/default/files/field/publicatii/ancheta structurala in agricu ltura 2016 vol1 1 .pdf

[26.] Institutul Naţional de Statistică, Anuarul Statistic al României, (2019): Letöltés dátuma: 2020. március 28. forrás: www.insse.ro

[27.] Ionescu, C. A. - Paschia, L. - Coman, M. D. (2019): Romanian Agriculture and Sustainable Development. In C. Ignătescu (ed.), 11th LUMEN International Scientific Conference Communicative 
Action \& Transdisciplinarity in the Ethical Society. CATES 2018 | 23-24 November 2018 Targoviste, Iasi: LUMEN Proceedings. pp. 156-169. DOI: $10.18662 /$ lumproc.108

[28.] Kemény G. - Lámfalusi I. - Tanító D. (2012): Az agrárgazdaság nemzetgazdasági szerepe az ágazati kapcsolatok mérlege alapján. Gazdálkodás, 56 (3), 201-210.

[29.] Kovács G. (2010): A mezőgazdasági szektor nemzetgazdasági jelentősége. Gazdálkodás, 54 (5), 466-478.

[30.] Kőmíves P.- Pilishegyi P.- Novák N.- Nagy A. - Körösparti P (2019): The role of the higher education in the development of the agriculture. International Journal of Information and Education Technology, 9 (9), 607-612.

[31.] Magda S. - Hajós L. - Dolmány F. (1998): A munkaeró gazudaságtana. Budapest: Dinasztia Kiadó.

[32.] Mănescu, C. - Ada, C. Oana, S.- Găvruța, A.-Teodor, M.- Toth, A. -Mateoc, S.(2016): Analysis of the importance of agriculture sector in Romanian economy. Scientific Papers Series Management Economic Engineering in Agriculture and Rural Development, 16 (1),

[33.] Péter E. K.- Illyés L. (2019): A helyi értékesítés szerepe Csíkszereda és vonzáskörzetében. Gazdálkodás, 63 (3), 204-217.

[34.] Popp J. - Szenderák J. - Fróna D. - Felföldi J. - Oláh J. - Harangi-Rákos M. (2018): A magyar mezőgazdaság teljesítménye 2004-2017 között. Jelenkori Társadalmi és Gazdasági Folyamatok, 13 (3-4), 9-20. DOI: $10.14232 /$ jtgf.2018.3-4.9-20

[35.] Radu, L. (2018): The Agricultural Crops Production of Romania, "Ovidius" University Annals. Economic Sciences Series, 18 (2), 177-181.

[36.] Samochiş, B. - Glogovețan, O. E. (2012): Polarization of Romanian Farms according to their size. Agriculture- Science and Practice, 21 (1-2) [8182], 139-146. DOI: 10.15407/agrisp

[37.] Steriu, V. - Otiman, I. (2013): Cadrul național strategic pentru dezvoltare durabilă a sectorului agroalimentar și a spațiului rural în perioada 2014-2020-2030. Cadrul național strategic rural. București : Editura Academiei Române.

[38.] Unguru, M. (2017). Analiza structurală an exploatațiilor agricole din România - probleme identificate și posibile oportunități de dezvoltare. EUROINFO, 1 (10), 57.

[39.] Vasa, L. (2011). Evaluation of the Hungarian transition model of the agriculture after the economic and political changes. Annals of Agrarian Science, 9 (3), 104-112.

\section{Szerző}

\section{Nagy Szeréna}

PhD-hallgató

Debreceni Egyetem, Gazdaságtudományi Kar

Vidékfejlesztés, Regionális Gazdaságtan és Turizmusmenedzsment Intézet

Ihrig Károly Gazdálkodás- és Szervezéstudományok Doktori Iskola

nagyszesze@yahoo.com 